\title{
Spray-Dried Dairy Product Categories
}

\author{
Ho, Minh Thao
}

CRC Press, Taylor \& Francis Group

2020-11-26

Ho , M T , Bansal , N \& Bhandari , B 2020 , Spray-Dried Dairy Product Categories . in C L Floch-Fouéré , P Schuck, G Tanguy , L Lanotte \& R Jeantet (eds), Drying in the Dairy Industry - From Established Technologies to Advanced Innovations . 1st edn , Advances drying science and technology , CRC Press, Taylor \& Francis Group , Boca Raton , pp. 1-24 . https://doi.org/10.1201/9781351119504

http://hdl.handle.net/10138/337158

https://doi.org/10.1201/9781351119504

acceptedVersion

Downloaded from Helda, University of Helsinki institutional repository.

This is an electronic reprint of the original article.

This reprint may differ from the original in pagination and typographic detail.

Please cite the original version. 


\title{
chapter 1
}

\section{Spray-dried dairy product categories}

\author{
Thao Minh Ho, Nidhi Bansal, and Bhesh Bhandari
}

AU: Please specify ' $a / b$ ' for reference citation 'Patel et al. $(2014)^{\prime}$.

\subsection{Introduction}

Spray drying is a common technique used to convert a liquid, a slurry, an emulsion, a suspension or a low viscosity paste into dried powder. This process involves atomizing (or spraying) the feed material into very small droplets which subsequently come into contact with a hightemperature air-drying medium in a drying chamber. The large surface area of the atomized droplets of the feed material imparts a very fast drying rate (Woo, 2017). Due to the unique characteristics of the spray-drying process, especially its short drying time and rapid water evaporation, it has been used not only in the food and dairy industries, but also in many other industrial sectors such as pharmaceuticals, agrochemicals, chemicals, detergents, pigments, biotechnology and ceramics (Broadhead et al., 1992; de Souza et al., 2015; Cao et al., 2000; Patel et al., 2014). In these fields, spray drying has been employed for three main purposes: (i) to dehydrate products for improving preservation, ease of handling, transport and storage; (ii) to encapsulate bioactive compounds within a protective matrix; and (iii) to induce the structural (phase) transformation of solid materials to obtain dried powders with distinct properties (Ho et al., 2017). However, in the scope of this chapter, only specific applications of spray drying for the production of dairy products are addressed. Although spray drying was introduced to the market in the 1920s and became popular in the dairy industry in the 1970s, with recent technical advances and innovations, the number of dairy products produced by spray drying has increased exponentially (Pisecky, 1985; Schuck, 2002). In the production of dairy products, spray drying is not limited to conventional milk powders (skim milk powder [SMP] and whole milk powder [WMP]), but has expanded to high protein and lactose powders (caseinate, milk protein concentrates [MPC] and whey protein powders), high fat powders (cream powder and butter powder) and even encapsulated powders (Table 1.1). The final dried products can be free-flowing powders of individual particles, agglomerates or granules depending on the properties of the feed materials and the conditions of spray drying. The physiochemical and functional properties of these products are greatly influenced by the spray-drying conditions and the post-spray-drying treatment of powders. In this chapter, the basic fundamentals of a spray-drying operation unit, and the compositions and key processing steps of such dried dairy products are discussed.

\subsection{The fundamentals of the spray-drying process in the production of dairy products}

Many aspects of the spray-drying unit operation relating to the production of food powders, such as heat and mass transfer, drying kinetics and the characteristics of the different components in a typical spray-drying system, the different types of spray dryers 
Table 1.1 Applications of spray drying in the production of dairy powders

\begin{tabular}{|c|c|}
\hline Applications & Typical products \\
\hline Dehydration & $\begin{array}{l}\text { Conventional milk powders (regular, instant or agglomerated forms): } \\
\text { - Skim milk powders (SMP) } \\
\text { - Whole milk powders (WMP) } \\
\text { - Infant formula milk powders } \\
\text { High protein and lactose powders: } \\
\text { - Caseinate powders } \\
\text { - Milk protein concentrates (MPC) } \\
\text { - Milk protein isolates (MPI) } \\
\text { - Whey protein powders (sweet whey powder, acid whey } \\
\text { powder, demineralized whey powder, delactosed whey } \\
\text { - powder) } \\
\text { - Whey protein concentrates (WPC) } \\
\text { High fat powders (fat content } 440-88 \%) \text { : } \\
\text { - Cream powders } \\
\text { - Butter powders } \\
\text { - Cheese powders }\end{array}$ \\
\hline $\begin{array}{l}\text { Encapsulation } \\
\text { matrix }\end{array}$ & $\begin{array}{l}\text { - Oils (flavor oils, essential oils, butter oil and fish oil) } \\
\text { - Useful bacteria and probiotics } \\
\text { - Food colors and vitamins }\end{array}$ \\
\hline
\end{tabular}

Source: Refstrup (1995).

and so on, have been well described elsewhere (Masters, 1985; Anandharamakrishnan and Ishwarya, 2015; Bhandari et al., 2008; Filkova and Mujumdar, 1995; Woo, 2017; Woo and Bhandari, 2013). Therefore, only the basic fundamentals of the spray-drying process are given in this section. Due to the high energy consumption during the spray-drying operation, the removal of water from the feed prior to spray drying is typically required to increase the solid concentration to a certain level via alternative energy efficiency approaches such as reversed filtration and evaporation to keep energy costs to a minimum. For example, in the production of SMP and whey powders, milk and whey feeds are typically concentrated to $25 \%$ and $42-60 \%$ total solids, respectively, via the reverseosmosis membrane and vacuum evaporation systems before they are subjected to spray drying (Masters, 1985; Roy et al., 2017). The energy required to evaporate $1 \mathrm{~kg}$ of water during spray drying is three to six times higher than that of a double-effect vacuum evaporator (Carić, 1994) and more than double than in the membrane concentration. Moreover, the preconcentration of the feed for spray drying enables the acquisition of the dried powders' desirable properties. The milk powders produced from preconcentrated milk have a large particle size, a small amount of entrapped air and a long shelflife due to the increase in viscosity and to the possible crystallization of lactose during preconcentration. Hence, the preconcentration of the feed can be considered an essential pre-treatment step in the spray drying of dairy powders.

The essential parts of a typical spray drier include the feed pump, atomizer, drying chamber, air heating and dispersing system, a product recovery system (cyclone) and a process control system. Figure 1.1 illustrates typical spray-drying equipment and the associated processing conditions that greatly affect the properties of the dried product. In terms of operation, spray drying is a continuous multi-stage unit involving (i) the atomization 


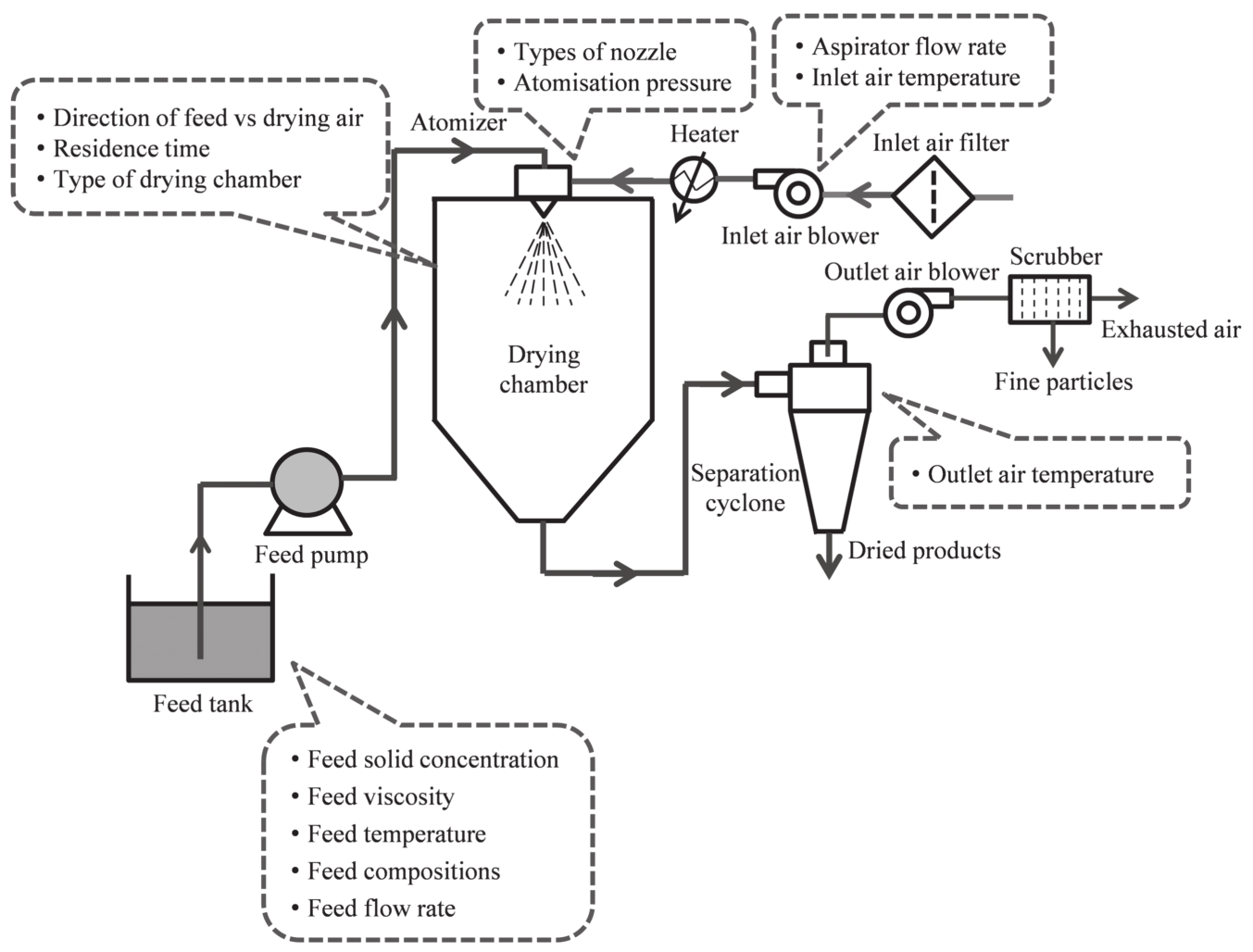

Figure 1.1 A diagram of typical spray drying indicating the main steps in the spray-drying process and associated processing conditions affecting the dried product properties. Adapted with permission from Ho et al. (2017).

of the feed solution, (ii) mixing of the sprayed droplets and hot air, (iii) the evaporation of water and (iv) the separation of dried products from exhausted air (Anandharamakrishnan and Ishwarya, 2015). The atomization stage is the most important operation in spray drying because it determines the trajectory, speed, shape, structure and size distribution of the droplets, and thus the design of the drying chamber and the particle size of dried products (Ho et al., 2017). The feed is supplied to an atomizer located on the top of the spray dryer via a feed pump. Typically, centrifugal pumps, positive displacement pumps or peristaltic pumps are the most commonly used types in the spray drying of dairy products depending on the feed rate, the viscosity of the feeds and the type of atomizer used. However, the feed pump is dependent on the feed properties (e.g. viscosity, surface tension, temperature and concentration), the type of atomizer and the feed amounts to be pumped. Under atomization, the feed is sprayed into micron-size droplets with a very large surface area. In thermodynamics, the rate of heat and mass transfer is directly proportional to the effective surface area. Thus, such a large surface area of atomized droplets facilitates rapid water evaporation and a short drying time. Several common types of atomizers are used to disintegrate the droplets from the feed, such as a rotary atomizer, a pressure nozzle atomizer, a two-fluid nozzle atomizer, an ultrasonic atomizer or an electrohydrodynamic atomizer. Each atomizer is different in terms of its energy requirements. The characteristics and operating principles of these atomizers were documented by Masters (1985), Anandharamakrishnan (2015) and Bhandari et al. (2008). The selection of a suitable 
atomizer is based on the physical properties of the feed, the design of the drying chamber and the desired final properties of the dried powders.

Upon leaving the atomizer, the droplets come into contact with hot drying air in three basic ways: (i) concurrent flow (e.g. the droplets and the hot drying air travel in the same direction); (ii) countercurrent flow (e.g. the droplets and the hot drying air travel in the opposite direction); and (iii) mixed flow (e.g. the droplets and the hot drying air travel in random direction providing higher levels of mixing and longer residence time). In the production of dairy products, the concurrent flow is the most operated mode due to the short residence time of particles that allows the dried particles to avoid passing through the high-temperature drying zone. As a result, undesirable changes in many bioactive components present in the materials are prevented during spray drying (Bhandari et al., 2008). In the drying chamber, due to the huge surface area of the atomized droplets, water evaporation from the atomized droplets occurs within a fraction of a second and within a very short travelling distance. The formation of a crust (e.g. drying boundary layer) on the surface of the powder particles occurs so fast that the spray-drying process can be considered to include only a falling rate period, especially the spray drying of small droplets that have a high amount of dissolved solids (Anandharamakrishnan, 2015). The dried powders are typically collected from the bottom of the drying chamber and discharged. Depending on the type of spray dryer, the operating conditions and the material properties, the exhausted air in the spray-drying system can carry about $10-50 \%$ of the total powder (Pisecký, 1997). Separating the powder from the exhausted air not only improves the drying yield but also minimizes air pollution. This can be done using either cyclones or a combination of cyclones and bag filters (even wet scrubbers). Beside the limitations on the cost-effectiveness and energy efficiency of spray drying, in comparison with other drying techniques used in the production of dairy powder, spray drying offers many advantages as illustrated in Table 1.2.

One of the major problems associated with spray drying most dairy powders is the stickiness and caking of the powder particles. This results from the collision of insufficiently powder dried particles with other particles (cohesion forces) and/or with drying walls (adhesion forces) (Boonyai et al., 2004). The stickiness of the powders during spray drying leads to many operating problems (difficulties in cleaning, possibility of blockage in the ducts or cyclone and fire hazards), a deterioration in product quality (possibility of overheating resulting in unpleasant sensory characteristics and degradation) and a low product yield due to wall deposition of the dried powders (Papadakis and Bahu, 1992).

Two mechanisms can explain the stickiness between the powder particles in spray drying dairy products. The first mechanism is related to the changes in the thermodynamic

Table 1.2 Advantages and disadvantages of spray drying in the production of dairy powders

\begin{tabular}{ll}
\hline Advantages & \multicolumn{1}{c}{ Disadvantages } \\
\hline - Continuous operation & - Expensive with high installation \\
- Flexible production rates and capacity design & costs \\
- Wide range of operating temperatures & - High energy requirement \\
- Short residence time and rapid drying & - Heat degradation possibility due to \\
- Suitable for both heat-sensitive and heat-resistant & high temperature of air drying \\
materials & - Stickiness of dried powders in the \\
- Possibility for automatic operation and maintenance & drying chamber resulting in \\
- Production of powdered products with & congestion, low yield and \\
predetermined characteristics and without requiring & difficulties in cleaning \\
further grinding & \\
\hline
\end{tabular}


state of amorphous components. During spray drying, water evaporation occurs so fast that the solutes do not have sufficient time to rearrange into an ordered structure (Ho et al., 2017). The main amorphous components present in spray-dried dairy powders are proteins and lactose. However, as compared to the proteins, the lactose dominates the changes in the physical properties observed in dairy powders (Roos, 2002). Thus, the stickiness of spraydried powder particles is usually associated with the lactose components. During spray drying, as the water content is reduced, the temperature of the atomized droplets increases. At glass transition temperature $\left(T_{g}\right)$, the amorphous lactose transforms from an immobile glass state to a rubbery state. A decrease in the viscosity on the particle surface in the rubbery phase leads to an increase in the mobility of the lactose molecules which results in the formation of rubbery bridges between adjacent particles. If the amorphous lactose remains above $T_{g}$ for sufficient time, the crystallization of the amorphous lactose and the formation of solid bridges between the powder particles occur (Foster, 2002). It was reported that signs of stickiness of dairy powders occur at a surface viscosity of about $10^{6}-10^{8}$ Pa.s (Downton et al., 1982). The stickiness of dairy powders caused by the amorphous components can be avoided by spray drying at temperatures lower than $20^{\circ} \mathrm{C}$ above their $T_{g}$ (Bhandari et al., 1997). It is observed that the mobility of the amorphous molecules is greatly affected by the moisture content, temperature and relative humidity to which the materials are exposed. An increase in the moisture content reduces $T_{g}$ and the activation energy to rearrange the molecules, enhancing the stickiness (Roos and Karel, 1992; Wang and Langrish, 2007). The second mechanism associated with the stickiness of spray-dried dairy powders relates to the melting of fat. In the spray drying of high fat milk powders, as the temperature of the drying medium is much higher than the melting temperature of fat, most fat transforms into a fluid-like state and tends to migrate over the particle surface due to its hydrophobic nature. The melting of fat facilitates the formation of liquid bridges between the powder particles. As the temperature drops below the melting temperature of fat, these bridges partially solidify, resulting in stickiness and caking of the powders (Foster, 2002). Moreover, the crystallization of lactose can stress the fat droplets inside the powder particles and force the fat to spread over the powder surface, imparting the stickiness between the powder particles (Fäldt and Bergenståhl, 1996). However, the contribution of fat to the stickiness of the dairy powders is only significant when it is present in amounts large enough to prevent encapsulation by proteins (O'Callaghan and Hogan, 2013).

As mentioned, the stickiness of the powders in the spray-drying process is described by both cohesion and adhesion phenomena. While the adhesion phenomenon is governed by viscoelastic behavior, phase transformation and melting of the surface fat, the cohesion phenomenon is determined by differences in the surface energy between the dried products and the equipment. The stickiness caused by the adhesion of the powder to the dryer wall plays a role in the early stage of the drying process. When the equipment wall is completely covered with the powders, stickiness is then governed by the cohesive forces between the particles. Thus, it is important to avoid the early stage of adhesion which can act as a seed for further accumulations of sticky particles (Bhandari and Howes, 2005). In order to minimize and/or avoid stickiness of the dried dairy powders, many approaches have been reported; however, some of them are not readily available commercially because of the incomplete understanding about new systems (Bhandari and Howes, 2005; Bhandari et al., 1997; Woo, 2017), such as:

a) Spray drying at low drying temperatures and low humidity conditions, and the introduction of cold air with controlled relative humidity at the end of the drying chamber or cooling the drying chamber wall to minimize the phase transformation and the melting of fat. 
b) Use of a two-stage spray-drying process in which fluidized bed drying at mild temperatures is integrated into the bottom of the spray-drying chamber to provide further drying of partially dried powder particles in the spray-drying stage, to induce partial crystallization of the lactose or to act as an agglomeration unit. Due to the low drying temperature during fluidized bed drying and the short residence time in a spray-drying section in the two-stage spray-drying system, thermal degradation of the products can be avoided.

c) Intermittent sweeping of the drying chamber wall with dehumidified cold air to prevent the stickiness of the powder on the drying wall.

d) Spray drying in a conical drying chamber (to minimize the adhesion of the drying powders to the dryer wall) and a concurrent flow (to avoid overheating the drying powders).

In spray drying, the powder particles are usually small $(<50 \mu \mathrm{m}$ in diameter), resulting in poor flowability and slow reconstitution or lump formation during rehydration. Thus, the manipulation of the powder agglomeration can lead to an increase in the dissolution rate of the powder due to an increase in the particle size and changes to the powder structure. There are two common ways to produce agglomerated milk powders, known as agglomeration in a drying chamber and fluidized bed agglomeration. In the first method, the fine powder particles travelling in exhausted air are collected and recirculated back to the drying chamber. Once they are in contact with the drying air and the atomized milk droplets, their surfaces are humidified (by the evaporated water) and become sticky. The adhesion of other drying particles on such surfaces due to the mixing actions in the drying chamber results in the agglomeration of the particles. In a fluidized bed agglomeration, a vibrating multi-section fluid bed with a perforated bottom is connected to the discharge opening of the drying chamber. When the powder from the drying chamber enters the first section of the fluid bed, steam is introduced to humidify the powder particles. Then, the humidified powder particles are conveyed to the drying section with a decreasing temperature to induce the agglomeration of the powder particles and further the dehydration of the agglomerated powders (Tetra Pak, 2018). In many cases, food-grade surfactants (primarily lecithin) can be sprayed onto the particles within the fluidized bed to produce high fat instant milk powders (Woo, 2017).

\subsection{Spray-dried dairy powder products}

Many commercial dairy powder products such as whey protein powders and caseinate powders are produced either by spray drying or roller drying. The differences in the dehydration mechanism between spray drying and roller drying lead to dissimilarities in the properties and functionality of milk powders. An example for caseinate powders is illustrated in Table 1.3 (DMV, 2012). However, in the scope of this chapter only spray-dried dairy powders are introduced. The production steps for the different types of spray-dried dairy powders are shown in Figures 1.2 and 1.3.

\subsubsection{Conventional dairy powders}

Conventional spray-dried milk powders include non-fat milk powder (NFMP), SMP and WMP. They can be in either regular or agglomerated form.

\subsubsection{Skim milk and non-fat milk powders}

In terms of composition, NFMP and SMP are very similar, but different in their requirements for protein content. SMP must have a minimum protein content of $34 \%$ while NFMP 
Table 1.3 Differences in the properties of spray-dried and rollerdried caseinate powders

\begin{tabular}{lcc}
\hline Properties & Roller drying & Spray drying \\
\hline Particle size $(\mu \mathrm{m})$ & $<500$ & $<800$ \\
Morphology & Spherical & Irregular \\
Bulk density $(\mathrm{g} / \mathrm{L})$ & $350-400$ & $470-520$ \\
Dispersibility & Relatively poor & Better \\
Flowability & Medium to poor & Good \\
Viscosity $\left(15 \%, 20^{\circ} \mathrm{C}\right)($ Pa.s $)$ & 2.5 & 3.0 \\
Occluded air & A lot & A little \\
\hline
\end{tabular}

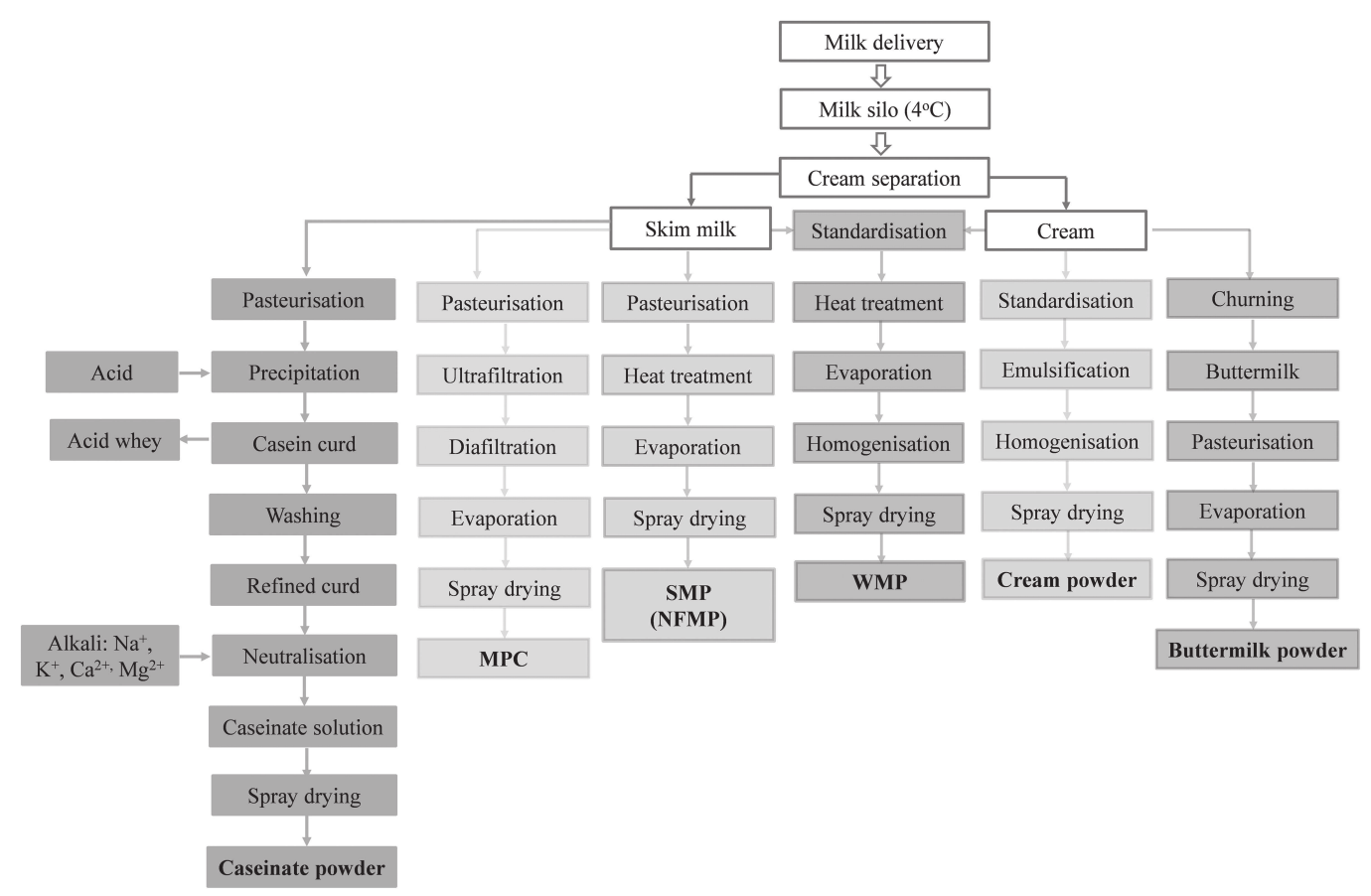

Figure 1.2 A sketch illustrating the main steps in the production of different types of milk powders: caseinate powder, MPC - milk protein concentrate, SMP - skim milk powder, NFMP - non-fat milk powder, WMP - whole milk powder, cream powder and buttermilk powder.

does not have any standard for protein content (Tetra Pak, 2018). The main composition of SMP is shown in Table 1.4 (Deeth and Hartanto, 2009). Both SMP and NFMP are produced from skim milk using a similar procedure including heat treatment, evaporation and spraydrying stages (Figure 1.2). The heat treatment not only destroys bacteria and inactivates enzymes in milk but it also controls the denaturation degree of whey proteins. Depending on the heat treatment conditions, different types of SMP with different functional properties and applications are manufactured (Table 1.5). An increase in heat treatment intensity increases the denaturation degree of whey proteins, reducing the solubility of the produced SMP (Bhandari et al., 2008). Pasteurization at $70-80^{\circ} \mathrm{C}$ for $15-50 \mathrm{~s}$ is typically applied for low heat SMP production while both pasteurization and subsequent heat treatment at $90-100^{\circ} \mathrm{C}$ for $30-50 \mathrm{~s}$ and $115-125^{\circ} \mathrm{C}$ for $1-4$ min are used for medium and high heat counterparts, 


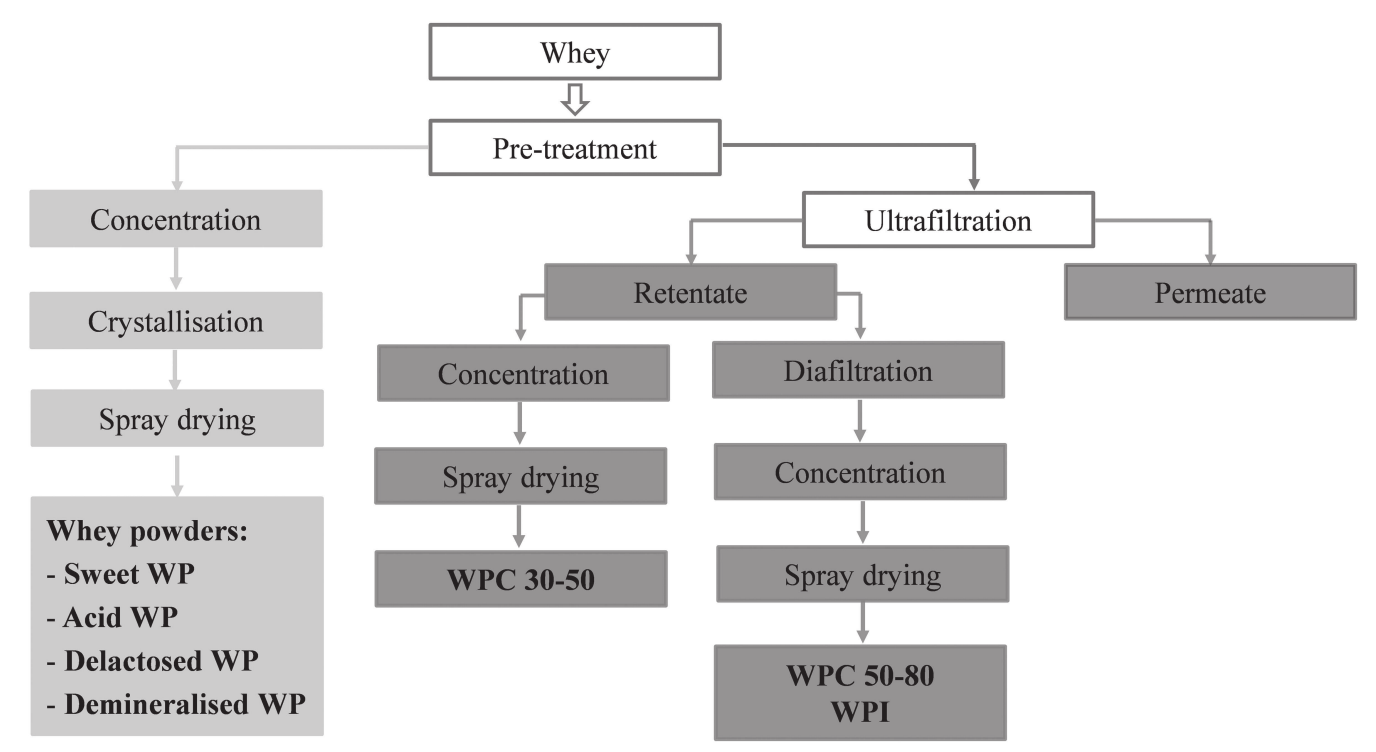

Figure 1.3 A sketch illustrating the main steps in the production of different types of whey-based powders: WP - whey powder, WPC - whey protein powder, WPI - whey protein isolate.

Table 1.4 Composition of SMP and WMP

\begin{tabular}{lcc}
\hline Composition $(\%, \mathrm{w} / \mathrm{w})$ & SMP & WMP \\
\hline Moisture content & $3.0-5.0$ & $2.0-4.0$ \\
Proteins & $35.0-37.0$ & $25.0-28.0$ \\
Fat & $0.7-1.3$ & $25.0-27.0$ \\
Lactose & $49.0-52.0$ & $37.0-38.5$ \\
Ash & $8.2-8.6$ & $6.0-7.0$ \\
\hline
\end{tabular}

Table 1.5 Different types of SMP

\begin{tabular}{|c|c|c|c|}
\hline Differences & Low heat SMP & Medium heat SMP & High heat SMP \\
\hline Heat treatment & $70-80^{\circ} \mathrm{C} / 15-50 \mathrm{~s}$ & $90-100^{\circ} \mathrm{C} / 30-50 \mathrm{~s}$ & $115-125^{\circ} \mathrm{C} / 1-4 \mathrm{~min}$ \\
\hline $\begin{array}{l}\mathrm{WPNI}^{*}(\mathrm{mg} \\
\mathrm{WPN} / \mathrm{g})\end{array}$ & $>6$ & $1.5-1.9$ & $<1.5$ \\
\hline Solubility & Highest & Medium & Lowest \\
\hline Applications & Reconstituted milk & $\begin{array}{l}\text { Ice cream, sweetened } \\
\text { condensed milk, } \\
\text { confectionery }\end{array}$ & Bakery products \\
\hline
\end{tabular}

* WPNI is the whey protein nitrogen index.

respectively. Due to the low solid concentration of skim milk (12-14\%, w/w), it is typically concentrated under a vacuum evaporator to $50-55 \%(\mathrm{w} / \mathrm{w})$ total solids prior to spray drying with inlet and outlet air temperatures of $180-230^{\circ} \mathrm{C}$ and $70-95^{\circ} \mathrm{C}$, respectively (Bhandari et al., 2008). Due to the high lactose content (49-52\%, w/w) in amorphous structures induced by rapid water evaporation during spray drying, SMP is very hygroscopic and prone to 
sticking and caking during handling, transport and storage. The partial crystallization of lactose prior to spray drying can minimize these unwanted changes to skim milk powders.

\subsubsection{Whole milk powders}

The production of WMP follows a similar procedure to the manufacture of SMP (Figure 1.2). However, raw milk is standardized by mixing a proportion of cream to skim milk to give a minimum fat content of $25 \%(\mathrm{w} / \mathrm{w})$ in the final powder. Moreover, a two-stage homogenization (15-20 MPa in the first stage and 3-5 MPa in the second stage) is normally carried out between the evaporation and spray-drying steps to prevent the cream from separating (Ranken et al., 1997). Due to the presence of a high fat content in standardized milk, spray drying is accomplished at a slightly lower air-drying temperature than that used for SMP production to prevent the stickiness of milk powder (Bhandari et al., 2008). A high fat free content on the particle surface makes WMP prone not only to stickiness and caking, but also to fat oxidation and difficulties in agglomeration and rehydration. Lecithin is usually added to the powder to improve its wettability during reconstitution.

\subsubsection{High protein milk powders}

\subsubsection{Caseinate powders}

The general process in the production of caseinate powders is shown in Figure 1.2. Caseinate powders are produced from either freshly precipitated acid casein curds (obtained by mixing pasteurized skim milk with food-grade acids until the isoelectric point of caseins is reached) or from dry acid caseins via a reaction with an alkali solution (Sarode et al., 2016). Depending on the type of alkali solution used to neutralize refined acid casein curds, which are initially washed several times in water to remove any residual whey, various types of caseinate powders with different functionalities (such as sodium caseinate, calcium caseinate, potassium caseinate and ammonium caseinate powders) are produced. Sodium caseinate is the most widely used caseinate in food processing due to its steric stabilization mechanism in oil-water emulsions, its strong and long-lasting electrostatic combination and its water absorption ability (Badem and Uçar, 2017). In the food industry, sodium caseinate is often used as a protein source, as an ingredient in milk or cream substitutes and as an emulsifier or a humectant in dairy and meat products (DMV, 2012). In terms of popularity, calcium caseinate follows sodium caseinate. It is used in both pharmaceutical preparations and food processing as a supply source for both calcium and protein. Sodium caseinate and calcium caseinate are quite similar in composition, but different in functional properties, as shown in Table 1.6 (DMV, 2012; Sarode et al., 2016).

\subsubsection{Milk protein concentrate and milk protein isolate (MPI) powders}

MPC and MPI are other typical types of high protein milk powders, together with caseinate powders. While MPCs refer to milk powders containing less than $90 \%$ protein (a dry basic, d.b.), MPIs are milk powders with higher than $90 \%$ protein (d.b.) (Meena et al., 2017). Unlike caseinate powders which contain only caseins, proteins in MPCs and MPIs contain both caseins and whey proteins at the same ratio as is naturally found in milk, and remain in an almost undenatured state due to the minimum heat load applied during processing. Thus, they preserve their native functional properties (Patel et al., 2014). Depending on the processing conditions, especially the degree of ultrafiltration and diafiltration, several types of MPCs with different protein concentrations, ranging from 42 to $85 \%$ (d.b.) are 
Table 1.6 Composition and functional properties of sodium caseinate and calcium caseinate powders

\begin{tabular}{lll}
\hline Properties & \multicolumn{1}{c}{ Sodium caseinate } & Calcium caseinate \\
\hline Moisture content (\%) & 3.8 & 3.8 \\
Protein (\%) & 91.4 & 91.2 \\
Lactose (\%) & 0.1 & 0.1 \\
Fat (\%) & 1.1 & 1.1 \\
Minerals (\%) & 3.8 & 3.6 \\
pH & $6.5-7$ & $6.5-7$ \\
Molecular conformation in solution & Random coil & Micelle-like aggregates \\
Appearance of solution & Translucent & Opaque \\
Mouthfeel solution (2-5\%) & Sticky & Milk-like \\
Dispersibility & Slight tendency for lumps & Good \\
Solubility & Good & Good \\
Viscosity (relative) & High & Low \\
Emulsifying property & Very good & Good \\
Salt tolerance & Very high & Limited \\
Heat stability & Very high & High \\
\hline
\end{tabular}

Table 1.7 Composition of different types of MPC and MPI powders

\begin{tabular}{lccccc}
\hline Milk powders & \multicolumn{5}{c}{ Composition $(\%, w / w)$} \\
\cline { 2 - 6 } & $\begin{array}{c}\text { Moisture } \\
\text { content }\end{array}$ & Proteins & Fat & Lactose & Ash \\
\hline MPC 35 & $3.4-3.6$ & $35.4-35.7$ & $0.5-3.5$ & $49.6-53.0$ & $7.7-8.1$ \\
MPC 42 & 3.5 & 42.0 & 1.0 & 46.0 & 7.5 \\
MPC 50 & $3.8-4.5$ & $49.8-49.9$ & $0.53-2.7$ & $35.8-38.0$ & $7.7-7.8$ \\
MPC 56 & 3.8 & 57.1 & 1.3 & 30.1 & 7.7 \\
MPC 60 & $3.9-4.0$ & $56.4-60.8$ & $0.51-3.0$ & $19.5-24.0$ & $7.8-8.1$ \\
MPC 70 & 4.2 & 70.0 & 1.4 & 16.2 & 8.2 \\
MPC 75 & 5.0 & 75.0 & 1.5 & 10.9 & 7.6 \\
MPC 80 & 3.9 & 80.0 & 1.8 & 4.1 & 7.4 \\
MPC 85 & 4.9 & 85.0 & 1.6 & 1.0 & 7.1 \\
MPC 88 & 5.3 & 88.0 & 2.27 & 0.74 & 7.05 \\
MPI & $<6.0$ & $>89.5$ & $<2.5$ & $<5.0$ & $<8.0$ \\
\hline
\end{tabular}

produced and they are typically named according to their protein content, e.g. MPC 42, MPC 70, MPC 75, MPC 80 and MPC 85 containing about 42, 70, 75, 80 and 85\% protein, respectively, as shown in Table 1.7 (Deeth and Hartanto, 2009; Meena et al., 2017). Due to their high protein content, MPCs have a very broad application in the food industry. MPCs are used as ingredients in and replacements for WMP, SMP and NFMP in food formulation, cheese production and health-related products (Kelly, 2011). Low protein MPCs (42$50 \%$ proteins) are often used in cheese, yogurt and soup applications while high protein MPCs ( $>70 \%$ proteins) are typically used in beverages, medical foods, enteral foods and protein bar applications (Patel et al., 2014). 
The production of MPCs is well described in the literature (Kelly, 2011; Meena et al., 2017; Patel et al., 2014; Uluko et al., 2016). Typically, MPCs are obtained from pasteurized skim milk via advanced low heat separating technologies, i.e. membrane filtration processes (ultrafiltration with/without combination with diafiltration), followed by evaporation and spray drying (Figure 1.3). During the ultrafiltration of skim milk, high molecular weight substances such as proteins and residual fat are retained on the membrane and concentrated in the retentate, while low molecular weight substances such as water, lactose, soluble minerals and vitamins pass through the membrane with the permeate. In the production of high protein MPCs, e.g. MPC 80, diafiltration is commonly applied to further remove lactose and soluble minerals to increase the protein concentration (Meena et al., 2017; Patel et al., 2014). Ultrafiltration alone allows the proteins to be enriched up to $35-42 \%$ (d.b.), and with the additional assistance of diafiltration, the obtained protein concentration increases up to 85\% (d.b.) (Kelly, 2011). The presence of residual fat and micellar calcium phosphate is a limiting factor for increasing the protein concentration beyond $90 \%$. Therefore, in the production of MPI, microfiltration is performed to remove any residual fat. During filtration, an increase in the retentate viscosity due to the enrichment of the protein concentration causes a rapid decline in the permeate flux through the membrane. Thus, an additional thermal concentration via vacuum evaporation is required to increase the solid concentration in the retentate prior to undergoing spray drying. Controlling the heating conditions during the thermal concentration and spray-drying process is essential to preserve the quality and functionality of the proteins in MPC and MPI powders.

\subsubsection{High fat dairy powders}

High fat dairy powders have a higher than 35\% fat content (Varnam and Sutherland, 2001).

AU: Please provide details for reference citation 'CODEX,
2011 ' to add in the reference list or can we delet this citation.

However, according to the Codex Alimentarius standard (CODEX, 2011), they must contain at least $42 \%$ fat. Due to the unique functional properties of milk fat, high fat dairy powders have been used in the manufacture of many products such as ice cream, cheese, infant formula, chocolate, desserts, bakery products, pastry making and confectionery, dehydrated soups and sauces (Early, 1990; Himmetagaoglu and Erbay, 2019). Typical high fat dairy powders are cream powder and cheese powder. Their proximate compositions are shown in Figure 1.4 (Deeth and Hartanto, 2009; P1secký, 1997).

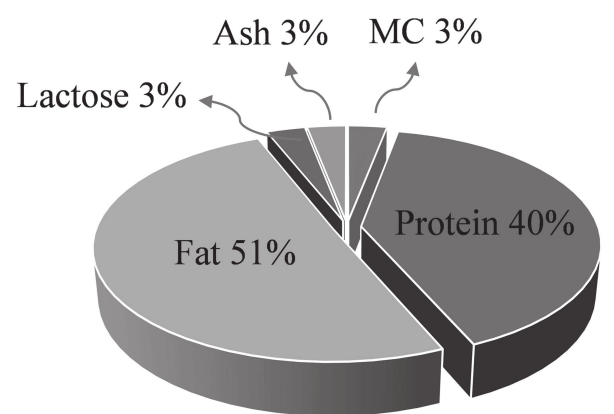

(a): Cheese powder

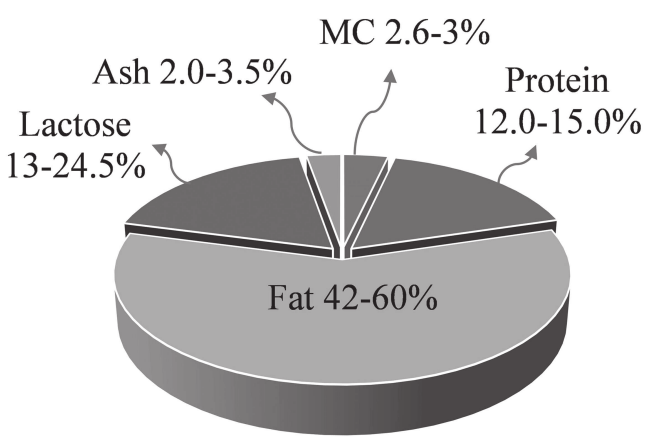

(b): Cream powder

Figure 1.4 The composition of cheese powder (a) and cream powder (b). 


\subsubsection{Cream powders}

The industrial process for cream powder production is similar to that for WMP; however, due to the high fat content in cream, the emulsification of cream is required to stabilize the fat. The most commonly used emulsifiers include caseinate, whey proteins, MPC or SMP depending on considerations related to the ability to stabilize fat and flavor (Havea et al., 2009). The high fat content of the cream emulsion also makes spray drying problematic because of the stickiness and caking of dried cream powder. It was reported that the stickiness of cream powder is a function of the air-drying temperature and air relative humidity (Paterson et al., 2007). An increase in the outlet air temperature from 30 to $50^{\circ} \mathrm{C}$ increases the stickiness of cream powder due to the fat melting, but a further increase to $80^{\circ} \mathrm{C}$ reduces the stickiness because the effects of a reduction in the surface viscosity on the stickiness are more profound than those of the melting fat. The cream powder contains a relatively high content of amorphous lactose (13-24.5\%) (Deeth and Hartanto, 2009). Thus, the stickiness of cream powder in spray drying is also caused by the phase transformation (amorphous to crystalline) of lactose which is greatly affected by the relative humidity of air drying. After spray drying, the surface of the cream powder particles is predominantly fat with approximately $99.0 \%$ (Kim et al., 2002). The high surface fat content of spray-dried cream powder makes it prone to fat oxidation during storage (Andersson and Lingnert, 1997, 1998a, 1998b). Thus, oxygen-eliminating packaging of cream powder (e.g. oxygen impermeable bags and nitrogen flushing of bags) is an efficient solution to enhance its shelf life. Also, lecithin may be sprayed on cream powders to improve their wettability.

\subsubsection{Cheese powders}

Aged cheese is often used as a starting material in the production of cheese powder to compensate for the loss of aroma and flavor during spray drying (Havea et al., 2009; Písecký, 2005). Four main steps are involved in cheese powder production (Figure 1.5). In the first stage, aged cheese and ingredients such as emulsifying water, salts, color agents, flavor agents, filling materials (such as SMP, maltodextrin, gelatinized starch) and antioxidants

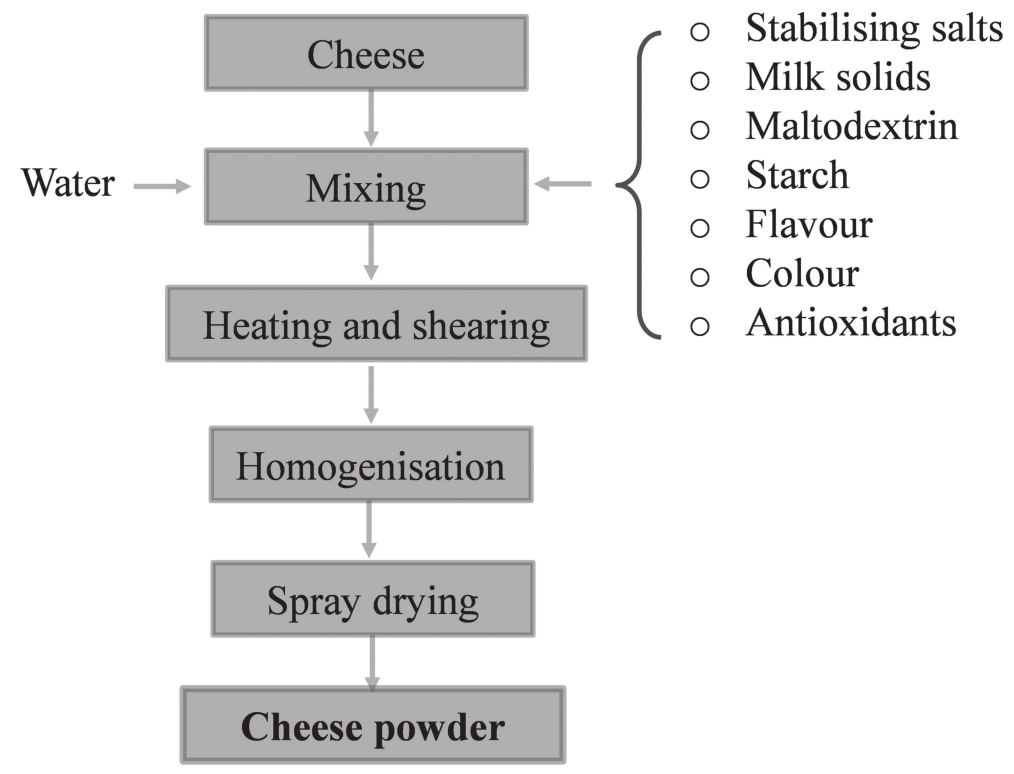

Figure 1.5 The general production procedure for cheese powder. 
are blended to produce a slurry with $35-40 \%$ of the total solid fraction. The mixture is then heated to $75-80^{\circ} \mathrm{C}$ with strong agitation until a hot molten slurry which is homogeneous in color and consistency and free of lumps or non-hydrated particles is obtained. The hot molten slurry is subsequently homogenized (15 MPa in the first stage and $5 \mathrm{MPa}$ in the second stage) to ensure homogeneity and the absence of free fat. Spray drying of the hot molten slurry is typically performed with an inlet air temperature of $180-200^{\circ} \mathrm{C}$ and an outlet air temperature of $85-90^{\circ} \mathrm{C}$ in a two-stage drying system with an integrated fluidized bed allowing the powder to cool to ambient temperature and to agglomerate. In spray drying cheese powder, the outlet air temperature is the most important parameter and it must not exceed $95^{\circ} \mathrm{C}$ (Fox et al., 2017). A higher outlet air temperature results in a higher rate of browning and Maillard reactions, lower solubility of cheese powder, a higher fat free content and lower acceptability in sensory properties (Erbay et al., 2015; Koca et al., 2015).

\subsubsection{Buttermilk powder}

Buttermilk powder is produced from spray drying buttermilk, a by-product of butter production. Its main composition is similar to that of SMP (Figure 1.6). During butter churning, a large proportion of fat goes into the butter, leaving the buttermilk with a low fat content. However, buttermilk has a large proportion of fat globule membrane materials which are rich in phospholipids (Deeth and Hartanto, 2009). It was reported that the amount of phospholipids in buttermilk $(0.72-0.88 \mathrm{mg} / \mathrm{g})$ is four to seven times higher than that in whole milk (0.12-0.14 mg/g) (Christie et al., 1987; Elling et al., 1996). Buttermilk powder has been used as an ingredient or an additive in the production of confectionery, bakery ice cream, desserts, candy bars and chocolates. The production protocol of buttermilk powder (Figure 1.2) is similar to that of low heat SMP (Farkye, 2006).

\subsubsection{Whey-based powders}

The most common whey-based powders are composed of whey powders (e.g. sweet whey powder, acid whey powder, demineralized whey powder and delactosed whey powder)

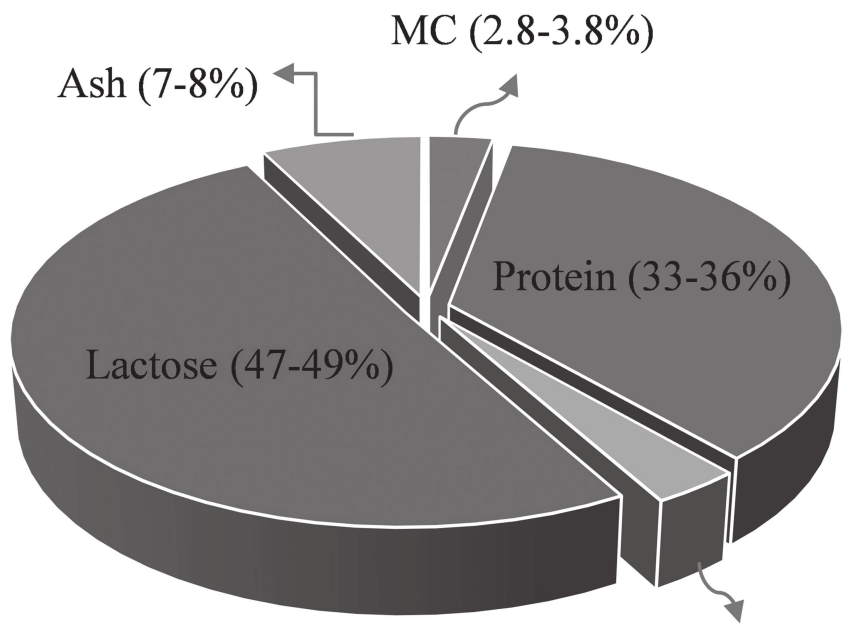

Fat $(3-6 \%)$

Figure 1.6 The composition of buttermilk powder. 
Table 1.8 Composition of different types of whey-based powders

\begin{tabular}{|c|c|c|c|c|c|}
\hline \multirow[t]{2}{*}{$\begin{array}{l}\text { Whey-based } \\
\text { powders }\end{array}$} & \multicolumn{5}{|c|}{ Composition $(\%, w / w)$} \\
\hline & MC & Proteins & Fat & Lactose & Ash \\
\hline \multicolumn{6}{|c|}{ Whey powders } \\
\hline Acid whey powder & $\leq 3.5$ & $9.0-12.0$ & 0.8 & $65.0-69.0$ & $11.0-12.0$ \\
\hline Sweet whey powder & $3.0-6.0$ & $12.0-13.0$ & $0.8-1.5$ & $70.0-73.0$ & $7.5-8.5$ \\
\hline $\begin{array}{l}\text { Demineralized whey } \\
\text { powder }\end{array}$ & $\leq 3.0$ & $\geq 11.0$ & $\leq 1.5$ & $78.0-82.0$ & $\leq 4.0$ \\
\hline $\begin{array}{l}\text { Delactosed whey } \\
\text { powder }\end{array}$ & $2.0-3.0$ & $18.0-25.0$ & $1.0-4.0$ & $40.0-60.0$ & $11.0-27.0$ \\
\hline \multicolumn{6}{|c|}{ Whey protein powders } \\
\hline WPC 35 & 4.6 & $34.0-36.0$ & $2.0-4.0$ & $44.0-53.0$ & $7.0-8.0$ \\
\hline WPC 50 & 4.3 & 53.0 & 5.0 & 35.0 & 7.0 \\
\hline WPC 65 & $3.0-4.0$ & $59.0-65.0$ & $4.0-6.0$ & $21.0-22.0$ & $3.5-4.0$ \\
\hline WPC 85 & $4.0-5.0$ & $72.0-81.0$ & $0.3-0.7$ & $2.0-13.0$ & $2.5-6.5$ \\
\hline WPI & $2.5-6.0$ & $89.0-93.0$ & $0.1-0.7$ & $0.1-0.8$ & $1.4-3.8$ \\
\hline
\end{tabular}

and whey protein powders (e.g. WPC and WPI). The approximate compositions and production steps of whey-based powders are shown in Table 1.8 (Deeth and Hartanto, 2009) and Figure 1.3.

\subsubsection{Whey powders}

Whey-based powders are produced from liquid whey, a by-product of either cheese manufacturing or casein/caseinate production. Liquid whey contains approximately $93 \%$ water. The main components in liquid whey are lactose and proteins which make up about 75 and $11.5 \%$ of total whey solids, respectively (Bansal and Bhandari, 2016; Qi and Onwulata, 2011). Depending on the type of agent (acids or rennet) used to precipitate caseins in cheese and casein/caseinate production, two main types of liquid whey with similar compositions are produced, namely sweet whey and acid whey. Sweet whey is obtained from rennet coagulation of milk at $\mathrm{pH}$ 6.0-6.5 while acid whey is a result of acid coagulation of milk at pH 4.5-5.0 (Tunick, 2008). The presence of casein fines and fat in whey has adverse effects on the production of whey-based powders; therefore, they should be immediately separated from whey via cyclones, centrifugal separators, vibrating screens or rotating filters after whey is produced. For short-term storage (less than $8 \mathrm{~h}$ ), whey must be quickly cooled to $5^{\circ} \mathrm{C}$ to minimize microorganism growth, while for long-term storage, whey is pasteurized. Depending on the type of whey-based powders (whey powders or whey protein powders), pre-treated whey is concentrated with different membrane-separating processes (Tetra Pak, 2018).

For the production of whey powders, pre-treated whey is often concentrated by reverse osmosis. However, the maximum concentration of whey obtained by reverse osmosis was reported to be about $20 \%$ because of the high osmotic pressure created by the concentrated lactose (Pearce, 1992). Thus, reverse osmosis is commonly used in combination with nanofiltration and/or vacuum evaporation to further increase the concentration of whey up to $50-60 \%$. Due to the high content of lactose, which could be the main cause for the stickiness of whey powders during drying, storage and handling, the lactose in whey should be crystallized via rapid cooling and by keeping the 
concentrated whey at a low temperature before spray drying. Depending on the source of whey (e.g. sweet or acid whey), whey powders can be classified as sweet whey powders or acid whey powders. Regarding delactosed whey powder, a part of the lactose is removed from whey prior to spray drying by either lactose crystallization followed by decanter centrifugation, ultrafiltration, diafiltration or hydrolysis. The high content of minerals in whey can impart a salty taste to whey powders, limiting their applications in food processing. These minerals can be removed from whey using a combination of various unit operations such as nanofiltration, ion exchange and electrodialysis, by which demineralized whey powder is produced.

\subsubsection{Whey protein concentrate and whey protein isolate powders}

The production process of WPC and WPI is quite similar to that of MPC and MPI, respectively. The pre-treated whey is subjected to a combination of various membrane separation processes such as microfiltration, ultrafiltration, nanofiltration, diafiltration and ion exchange to produce whey protein powders with different protein concentrations. Details of the production process for these types of whey-based powders have been well reported by various authors (Bansal and Bhandari, 2016; Boland, 2011; Chegini and Taheri, 2013; Morr and Ha, 1993; Onwulata and Huth, 2009; Zadow, 2012). Due to the nutritional values and functional properties of whey-based powders, they are used in a wide range of food products such as confectionery, bakery, dairy, meat/fish, dietetic foods, infant formula, nutraceuticals and pharmaceuticals (Ramos et al., 2016).

\subsubsection{Microencapsulated dairy powders}

Microencapsulation is a physical process in which active compounds (e.g. core materials) are covered by a continuous thin coating of wall materials to protect them from the adverse effects of the surrounding environment, to mask their undesired properties and to control their release rate under favored conditions (Barbosa-Cánovas et al., 2005). Among the reported common techniques for the production of microencapsulated food powders, spray drying is emerging as the most common and cheapest technique due to the exclusive characteristics of the spray-drying process. The application of spray drying in the production of microencapsulated food ingredients has been well described by Gharsallaoui et al. (2007). Figure 1.7 illustrates the main steps, together with factors affecting the production of microencapsulated dairy powder via spray drying, in order to control the encapsulation process and consequently to obtain the highest encapsulation efficiency and microcapsule stability (Bhandari et al., 2008). Depending on the properties of the core materials and the final products, the wall materials can be selected from either a single polymer (e.g. maltodextrin, gum arabic, alginate, carrageenan, lactose, sucrose, sodium caseinate, micellar casein, whey protein, soy protein isolate, gelatin and modified starch) or their mixture. Due to the nature of spray drying in which a homogeneous aqueous feed solution is required, an expected wall material should have high solubility in water and it should form a good emulsion with core materials. In many cases, in order to obtain a fine and stable emulsion of core material in a wall solution, an emulsifier is added to the solution of wall and core materials, and a homogenization step is performed. During the spray drying of the obtained emulsion, direct contact of the atomized droplets of emulsion with the high temperature drying air results in rapid water evaporation and fast solidification of the solute. Differences in the drying characteristics of wall materials and core dispersing solutions result in the formation of a coating around the core containing droplets during the falling rate drying period (Anandharamakrishnan, 2017). 
Many microencapsulated dairy powders in which either the wall materials or the core materials are dairy-based components have been produced by spray drying. In these products, different core materials such as oils, milk fat, volatile compounds and probiotics are encapsulated using milk protein and whey protein powders as coating materials aiming to prevent fat oxidation, to retain and control the release rate of volatile compounds and to improve the viability of microorganisms and their functionality during storage and food processing (Anandharamakrishnan, 2017; Burgain et al., 2015; Gharsallaoui et al., 2007). Some of these are illustrated in Table 1.9.

\subsubsection{Infant milk formula}

Powdered infant milk formula is produced as a substitute for breast milk when it is not available. Thus, its composition, nutritional properties and functions must be similar to those of breast milk to provide the same growth and development factors of an exclusively breastfed infant (Blanchard et al., 2013). Generally, powdered infant milk formula is produced via either a "dry mix" or a "wet mix" process, or a combination of both (Schuck, 2013). In the dry mix method, all the ingredients received from suppliers are in powder form and they are simply mixed together in large batches to obtain a uniform mixture. In some cases, a mixture of various ingredients is prepared using the wet mix process

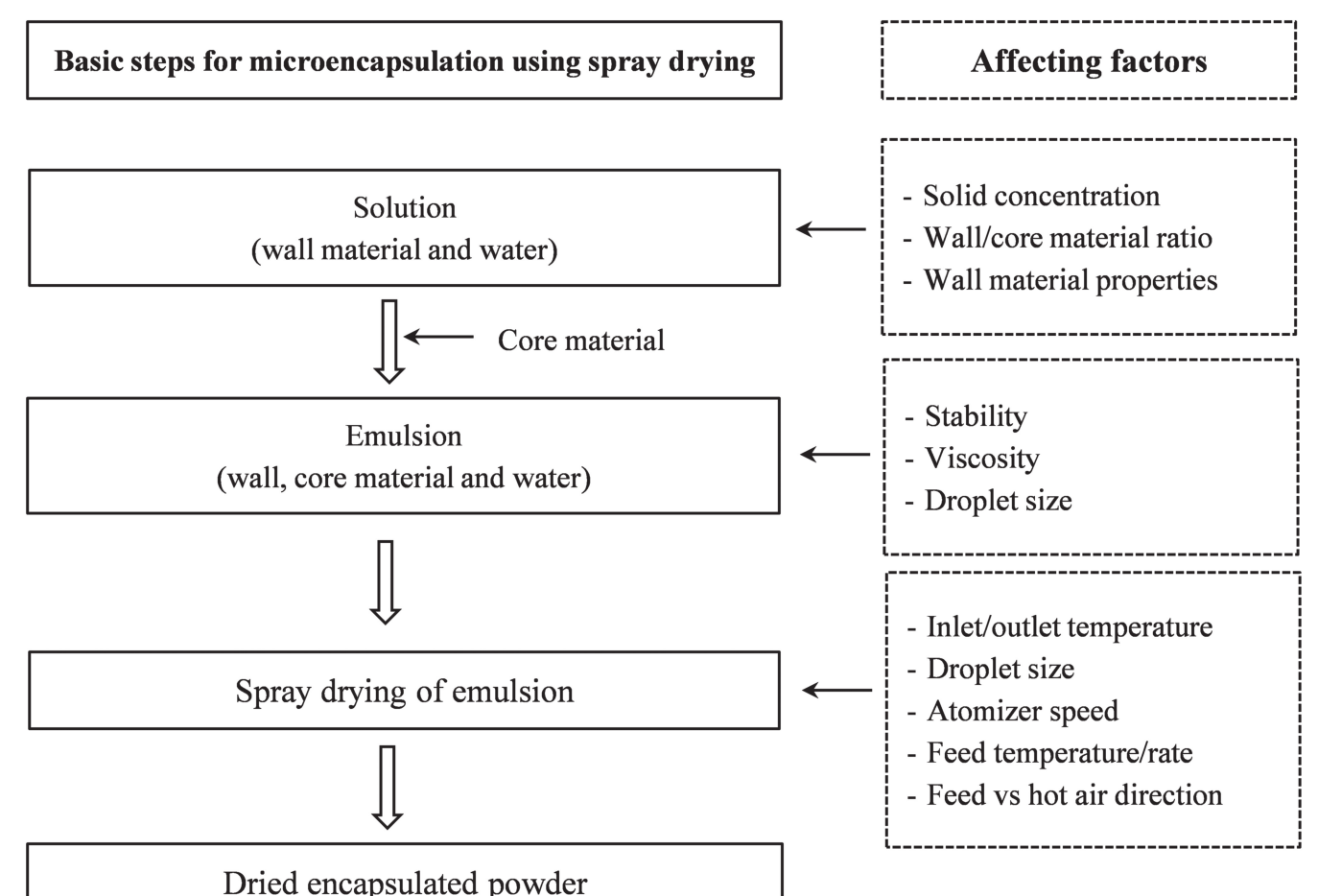

Figure 1.7 A schematic diagram illustrating the basic steps in the production of microencapsulated powder using spray drying and important factors affecting the efficiency of encapsulation. Redrawn with permission from Bhandari et al. (2008). 
to produce a base powder to which the remaining dry ingredients are added (Blanchard et al., 2013). Oversized particles can be removed from the mixture by sifting before inner gas packaging (Jiang and Guo, 2014). Regarding the wet mix processing method, although more complicated and costly than the dry mix method, it allows control over all aspects of the product quality. Thus, it is currently the most widely used method to produce powdered infant milk formula. A typical production line of powdered infant milk formula using the wet mix method is shown in Figure 1.8, which includes three main steps, namely preparation of the mix, evaporation and spray drying. Details of these steps have been well described by Montagne et al. (2009), Guo and Ahmad (2014), Blanchard et al. (2013) and Jiang and Guo (2014). The main advantages and disadvantages of the dry and wet mix process are presented in Table 1.10 (Montagne et al., 2009; Blanchard et al., 2013).

Table 1.9 Some typical applications of spray drying in the production of microencapsulated dairy powders

\begin{tabular}{|c|c|c|c|}
\hline Core materials & Wall materials & Main results & References \\
\hline Soybean oil & $\begin{array}{l}\text { Sodium caseinate } \\
\text { with/without } \\
\text { lactose }\end{array}$ & $\begin{array}{l}\text { Encapsulated powders } \\
\text { containing up to } 85 \% \text { of oil }\end{array}$ & $\begin{array}{l}\text { Fäldt and } \\
\text { Bergenståhl } \\
\text { (1995) }\end{array}$ \\
\hline Coconut oil & & $\begin{array}{l}\text { Coconut oil and butterfat } \\
\text { encapsulated powders } \\
\text { containing up to } 75 \% \text { of oil }\end{array}$ & \\
\hline \multicolumn{4}{|l|}{ Butterfat } \\
\hline Rapeseed oil & & $\begin{array}{l}\text { Almost completely } \\
\text { encapsulated }\end{array}$ & \\
\hline $\begin{array}{l}\text { Anhydrous milk fat } \\
\text { (AMF) }\end{array}$ & $\begin{array}{l}\text { Whey protein (WPC } \\
\& \text { WPI) with lactose }\end{array}$ & $\begin{array}{l}\text { Encapsulated powders } \\
\text { containing up to } 95 \% \text { of AMF }\end{array}$ & $\begin{array}{l}\text { Young et al. } \\
\text { (1993) }\end{array}$ \\
\hline Ethyl butyrate & $\begin{array}{l}\text { WPI with/without } \\
\text { lactose }\end{array}$ & Retention levels of $76 \%$ & $\begin{array}{l}\text { Rosenberg and } \\
\text { Sheu (1996) }\end{array}$ \\
\hline Ethyl caprylate & & Retention levels of $92 \%$ & \\
\hline Soya oil & WPC 75 & $\begin{array}{l}\text { Encapsulated powders } \\
\text { containing up to } 75 \% \text { of oil }\end{array}$ & $\begin{array}{l}\text { Hogan et al. } \\
\text { (2001) }\end{array}$ \\
\hline Avocado oil & $\begin{array}{l}\text { WPI with } \\
\text { maltodextrin }\end{array}$ & $\begin{array}{l}\text { Encapsulated powders } \\
\text { containing up to } 66 \% \text { of oil }\end{array}$ & $\begin{array}{l}\text { Bae and Lee } \\
\text { (2008) }\end{array}$ \\
\hline Milk fat & $\begin{array}{l}\text { Carbohydrate } \\
\text { matrices }\end{array}$ & $\begin{array}{l}\text { Encapsulated powders } \\
\text { containing up to } 60 \% \text { of } \\
\text { milk fat }\end{array}$ & $\begin{array}{l}\text { Onwulata et al. } \\
\text { (1996) }\end{array}$ \\
\hline $\begin{array}{l}\text { Saccharomyces } \\
\text { boulardii }\end{array}$ & $\mathrm{WPI}(\mathrm{pH}=4)$ & $\begin{array}{l}\text { High survival rate with } \sim 1.0 \\
\text { log reduction }\end{array}$ & $\begin{array}{l}\text { Diep et al. } \\
(2014)\end{array}$ \\
\hline $\begin{array}{l}\text { Lactobacillus } \\
\text { rhamnosus GG }\end{array}$ & $\begin{array}{l}\text { Micellar casein } \\
\text { powder and whey } \\
\text { protein powder }\end{array}$ & $\begin{array}{l}\text { Excellent survival rate with } \\
<0.5 \log \text { reduction }\end{array}$ & $\begin{array}{l}\text { Guerin et al. } \\
(2017)\end{array}$ \\
\hline $\begin{array}{l}\text { Lactobacillus } \\
\text { acidophilus La-5 }\end{array}$ & $\begin{array}{l}\text { SMP and sweet whey } \\
\text { powder }\end{array}$ & $\begin{array}{l}\text { High survival rate with } \sim 2.0 \\
\text { log reduction and viability } \\
\text { almost unchanged during } \\
\text { 90-day storage at } 4-25^{\circ} \mathrm{C}\end{array}$ & $\begin{array}{l}\text { Maciel et al. } \\
(2014)\end{array}$ \\
\hline $\begin{array}{l}\text { Saccharomyces } \\
\text { cerevisiae var. boulardii }\end{array}$ & WPC & Survival rate of $91.81 \%$ & $\begin{array}{l}\text { Arslan et al. } \\
\text { (2015) }\end{array}$ \\
\hline
\end{tabular}




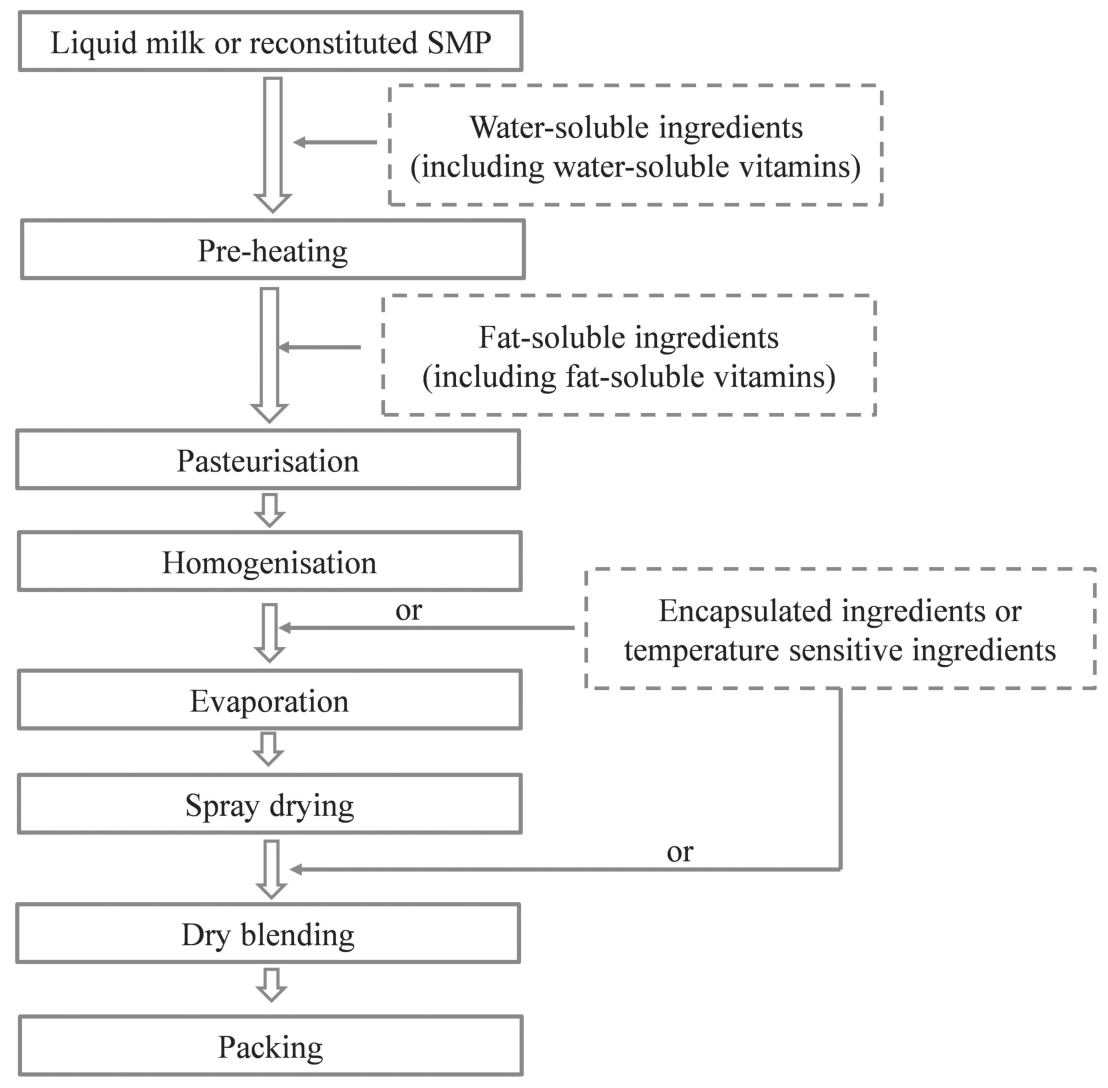

Figure 1.8 A schematic diagram illustrating the basic steps in the production of powdered infant milk formula using the wet mix method. Redrawn with permission from Jiang and Guo (2014).

\subsubsection{Lactose hydrolyzed milk powder}

Lactose hydrolyzed milk powder, also known as lactose-free milk powder, is produced using enzyme $\beta$-galactosidase (lactase) to hydrolyze the lactose in milk into monosaccharides (glucose and galactose) before the milk is subjected to pasteurization, homogenization, evaporation and spray drying (Dekker et al., 2019). In comparison to regular milk powders, the current market for lactose-free milk powder is still very small due to technical problems regarding its production and storage (Torres et al., 2017). The production of lactose-free milk powder is quite similar to that of whole milk powder (Figure 1.9). However, the formation of low glass transition temperature $\left(T_{g}\right)$ compounds (e.g. glucose with a $T_{g}$ of $\approx 31^{\circ} \mathrm{C}$ and galactose with a $T_{g}$ of $\approx 30^{\circ} \mathrm{C}$ ) during the hydrolysis of lactose $\left(T_{g}\right.$ of $\approx 101^{\circ} \mathrm{C}$ ) leads to a drop in the $T_{g}$ of lactose hydrolyzed milk, resulting in a series of problems during the spray drying and storage of lactose-free milk powder such as agglomeration, stickiness, caking, elevated hygroscopicity and browning (Fialho et al., 2018). 
Table 1.10 Main advantages and disadvantages of two methods to produce infant milk formula powder

\begin{tabular}{|c|c|c|}
\hline & Dry mix method & Wet mix method \\
\hline Advantages & $\begin{array}{l}\text { - Small investment cost } \\
\text { - Low energy consumption } \\
\text { - Safer from microbiological hazards due } \\
\text { to no water involvement }\end{array}$ & $\begin{array}{l}\text { - Ease to incorporate } \\
\text { hydrophobic compounds } \\
\text { (e.g. oils) } \\
\text { - Ease to control all aspects of } \\
\text { product quality } \\
\text { (microbiology, physical and } \\
\text { chemical properties) }\end{array}$ \\
\hline Disadvantages & $\begin{array}{l}\text { - Impossible to incorporate oils } \\
\text { - High dependence of powder properties } \\
\text { (physical properties - wettability and } \\
\text { solubility, and microbiological quality) } \\
\text { on the quality of the raw materials } \\
\text { - Possibility of post-process contamination } \\
\text { - Inhomogeneity in appearance and } \\
\text { composition of the product due to } \\
\text { different density ingredients }\end{array}$ & $\begin{array}{l}\text { - High investment and } \\
\text { production cost }\end{array}$ \\
\hline
\end{tabular}

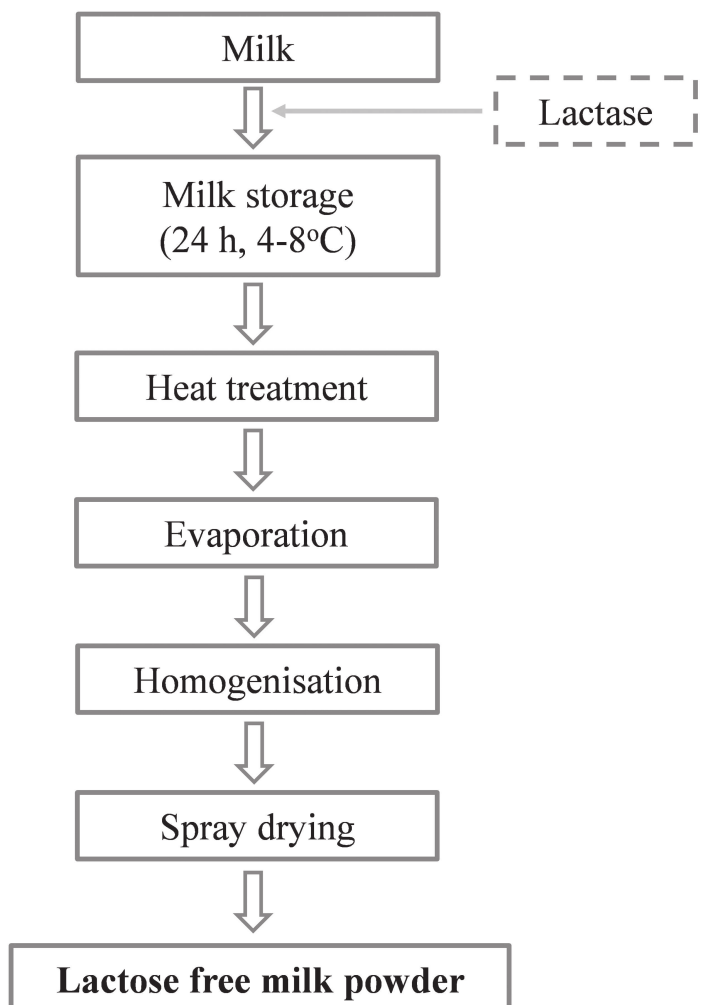

Figure 1.9 A schematic diagram illustrating the basic steps in the production of lactose-free milk powder. Redrawn with permission from Dekker et al. (2019). 


\subsection{Conclusion}

In this chapter, dried dairy products produced by spray drying are classified and briefly introduced with an emphasis on their composition and manufacturing process. With recent advances in spray-drying technologies, especially a better understanding of the stickiness mechanisms of dairy powders (a major problem in the spray drying of dairy powders), the application of spray drying in the production of dairy powders has greatly expanded. In terms of powder productions, spray drying has been utilized in the manufacture of conventional milk powders such as non-fat milk powder, SMP and WMP; high protein powders such as caseinate powder, MPCs and MPI, whey powders, WPCs and WPI; high fat powders such as cream powder, cheese powder and buttermilk powder; and encapsulated dairy powders. However, spray drying still has several challenges inspiring further research work. Most of them are related to energy consumption and product quality. Currently, the high drying temperature of spray drying prevents its application in the dehydration of other materials which contain high levels of heat-sensitive bioactive compounds, such as camel milk.

\section{References}

Anandharamakrishnan, C. (2015). "Spray drying techniques for food ingredient encapsulation". John Wiley \& Sons, Chichester, UK.

Anandharamakrishnan, C. (2017). "Handbook of drying for dairy products". John Wiley \& Sons, Chichester, UK.

Anandharamakrishnan, C., and Ishwarya, S. P. (2015). Introduction to spray drying. In "Spray drying techniques for food ingredient encapsulation" (C. Anandharamakrishnan and S. P. Ishwarya, eds.). John Wiley \& Sons, Ltd., Chichester, UK.

Andersson, K., and Lingnert, H. (1997). Influence of oxygen concentration on the storage stability of cream powder. LWT-Food Science and Technology 30(2), 147-154.

Andersson, K., and Lingnert, H. (1998a). Influence of oxygen concentration and light on the oxidative stability of cream powder. LWT-Food Science and Technology 31(2), 169-176.

Andersson, K., and Lingnert, H. (1998b). Influence of oxygen concentration on the flavour and chemical stability of cream powder. LWT-Food Science and Technology 31(3), 245-251.

Arslan, S., Erbas, M., Tontul, I., and Topuz, A. (2015). Microencapsulation of probiotic Saccharomyces cerevisiae var. boulardii with different wall materials by spray drying. LWT-Food Science and Technology 63(1), 685-690.

Badem, A., and Uçar, G. (2017). Production of caseins and their usages. International Journal of Food Science and Nutrition 2, 4-9.

Bae, E., and Lee, S. (2008). Microencapsulation of avocado oil by spray drying using whey protein and maltodextrin. Journal of Microencapsulation 25(8), 549-560.

Bansal, N., and Bhandari, B. (2016). Functional milk proteins: Production and utilization - Wheybased ingredients. In "Advanced dairy chemistry", pp. 67-98. Springer, New York.

Barbosa-Cánovas, G. V., Ortega-Rivas, E., Juliano, P., and Yan, H. (2005). "Encapsulation processes". Springer, New York.

Bhandari, B., and Howes, T. (2005). Relating the stickiness property of foods undergoing drying and dried products to their surface energetics. Drying Technology 23(4), 781-797.

Bhandari, B. R., Datta, N., and Howes, T. (1997). Problems associated with spray drying of sugar-rich foods. Drying Technology 15(2), 671-684.

Bhandari, B. R., Patel, K. C., and Chen, X. D. (2008). Spray drying of food materials - process and product characteristics. Drying Technologies in Food Processing 4, 113-157.

Blanchard, E., Zhu, P., and Schuck, P. (2013). Infant formula powders. In "Handbook of food powders" (B. Bhandari, N. Bansal, M. Zhang and P. Schuck, eds.), pp. 465-483. Woodhead Publishing, Cambridge.

Broadhead, J., Edmond Rouan, S. K., and Rhodes, C. T. (1992). The spray drying of pharmaceuticals. Drug Development and Industrial Pharmacy 18(11-12), 1169-1206. 
Boland, M. (2011). 3 - Whey proteins. In "Handbook of food proteins" (G. O. Phillips and P. A. Williams, eds.), pp. 30-55. Woodhead Publishing, Cambridge.

Boonyai, P., Bhandari, B., and Howes, T. (2004). Stickiness measurement techniques for food powders: A review. Powder Technology 145(1), 34-46.

Burgain, J., Corgneau, M., Scher, J., and Gaiani, C. (2015). Encapsulation of probiotics in milk protein microcapsules. In "Microencapsulation and microspheres for food applications" (M. C. S. Leonard, ed.), pp. 391-406. Elsevier, San Diego.

Cao, X. Q., Vassen, R., Schwartz, S., Jungen, W., Tietz, F., and Stöever, D. (2000). Spray-drying of ceramics for plasma-spray coating. Journal of the European Ceramic Society 20(14-15), 2433-2439.

Carić, M. (1994). "Concentrated and dried dairy products". VCH Publishers Inc., New York.

Chegini, G., and Taheri, M. (2013). Whey powder: Process technology and physical properties: A review. Middle-East Journal of Scientific Research 13, 1377-1387.

Christie, W., Noble, R., and Davies, G. (1987). Phospholipids in milk and dairy products. International Journal of Dairy Technology 40(1), 10-12.

de Souza, V. B., Thomazini, M., de Carvalho Balieiro, J. C., and Fávaro-Trindade, C. S. (2015). Effect of spray drying on the physicochemical properties and color stability of the powdered pigment obtained from vinification byproducts of the Bordo grape (Vitis labrusca). Food and Bioproducts Processing 93, 39-50.

Deeth, H., and Hartanto, J. (2009). Chemistry of milk-role of constituents in evaporation and drying. In "Dairy powders and concentrated products" (A. Y. Tamime, ed.), pp. 1-27. Blackwell Publishing, Chichester, UK.

Dekker, P. J., Koenders, D., and Bruins, M. J. (2019). Lactose-free dairy products: Market developments, production, nutrition and health benefits. Nutrients 11(3), 551.

Diep, D. T. N., George, P., Gorczyca, E., and Kasapis, S. (2014). Studies on the viability of Saccharomyces boulardii within microcapsules in relation to the thermomechanical properties of whey protein. Food Hydrocolloids 42, 232-238.

DMV (2012). Caseinate - The incredible milk protein. Vol. 2018. FrieslandCampina DMV https://ww w.foodingredientsfirst.com/technical-papers/caseinates-the-incredible-milk-protein.html.

Downton, G. E., Flores-Luna, J. L., and King, C. J. (1982). Mechanism of stickiness in hygroscopic, amorphous powders. Industrial and Engineering Chemistry Fundamentals 21(4), 447-451.

Early, R. (1990). The use of high-fat and specialized milk powders. International Journal of Dairy Technology 43(2), 53-56.

Elling, J., Duncan, S., Keenan, T., Eigel, W., and Boling, J. (1996). Composition and microscopy of reformulated creams from reduced-cholesterol butteroil. Journal of Food Science 61(1), 48-53.

Erbay, Z., Koca, N., Kaymak-Ertekin, F., and Ucuncu, M. (2015). Optimization of spray drying process in cheese powder production. Food and Bioproducts Processing 93, 156-165.

Fäldt, P., and Bergenståhl, B. (1995). Fat encapsulation in spray-dried food powders. Journal of the American Oil Chemists' Society 72(2), 171-176.

Fäldt, P., and Bergenståhl, B. (1996). Changes in surface composition of spray-dried food powders due to lactose crystallization. LWT-Food Science and Technology 29(5-6), 438-446.

Farkye, N. (2006). Significance of milk fat in milk powder. In "Advanced dairy chemistry Volume 2: Lipids" (P. F. Fox and P. L. H. McSweeney, eds.), pp. 451-465. Springer, New York.

Fialho, T. L., Martins, E., Silva, C. R. D. J., Stephani, R., Tavares, G. M., Silveira, A. C. P., Perrone, Í. T., Schuck, P., de Oliveira, L. F. C., and de Carvalho, A. F. (2018). Lactose-hydrolyzed milk powder: Physicochemical and technofunctional characterization. Drying Technology 36(14), 1688-1695.

Filkova, I., and Mujumdar, A. S. (1995). Industrial spray drying systems. In "Handbook of industrial drying", Vol. 1, 3rd Edition (A. S. Mujumdar, ed.), pp. 263-308. CRC Press, Boca Raton, FL.

Foster, K. (2002). The prediction of sticking in dairy powders: A thesis for the degree of Doctor of Philosophy in Bioprocess Engineering at Massey University. Massey University.

Fox, P. F., Guinee, T. P., Cogan, T. M., and McSweeney, P. L. H. (2017). Cheese as an ingredient. In "Fundamentals of cheese science" (P. F. Fox, T. P. Guinee, T. M. Cogan and P. L. H. McSweeney, eds.), pp. 629-679. Springer US, Boston, MA.

Gharsallaoui, A., Roudaut, G., Chambin, O., Voilley, A., and Saurel, R. (2007). Applications of spraydrying in microencapsulation of food ingredients: An overview. Food Research International 40(9), 1107-1121. 
Guerin, J., Petit, J., Burgain, J., Borges, F., Bhandari, B., Perroud, C., Desobry, S., Scher, J., and Gaiani, C. (2017). Lactobacillus rhamnosus GG encapsulation by spray-drying: Milk proteins clotting control to produce innovative matrices. Journal of Food Engineering 193, 10-19.

Guo, M., and Ahmad, S. (2014). Formulation guidelines for infant formula. In "Human milk biochemistry and infant formula manufacturing technology" (M. Guo, ed.), pp. 141-171. Woodhead Publishing, Cambridge, UK.

Havea, P., Baldwin, A. J., and Carr, A. J. (2009). Specialised and novel powders. In "Dairy powders and concentrated products" (A. Y. Tamime, ed.), pp. 268-293. Blackwell Publishing Ltd., Chichester, UK.

Himmetagaoglu, A. B., and Erbay, Z. (2019). Effects of spray drying process conditions on the quality properties of microencapsulated cream powder. International Dairy Journal 88, 60-70.

Ho, T. M., Truong, T., and Bhandari, B. (2017). Spray-drying and non-equilibrium states/glass transition. In "Non-equilibrium states and glass transitions in foods" (B. Bhandari and Y. H. Roos, eds.), pp. 111-136. Woodhead Publishing, Duxford, UK.

Hogan, S., McNamee, B., O'Riordan, E., and O'Sullivan, M. (2001). Microencapsulating properties of whey protein concentrate 75. Journal of Food Science 66(5), 675-680.

Jiang, Y. J., and Guo, M. (2014). Processing technology for infant formula. In "Human milk biochemistry and infant formula manufacturing technology" (M. Guo, ed.), pp. 211-229. Woodhead Publishing, Cambridge, UK.

Kelly, P. (2011). Milk protein products. In "Encyclopedia of dairy sciences", 2nd Edition (J. W. Fuquay, ed.), pp. 848-854. Academic Press, San Diego, CA.

Kim, E. H. J., Chen, X. D., and Pearce, D. (2002). Surface characterization of four industrial spraydried dairy powders in relation to chemical composition, structure and wetting property. Colloids and Surfaces, Part B: Biointerfaces 26(3), 197-212.

Koca, N., Erbay, Z., and Kaymak-Ertekin, F. (2015). Effects of spray-drying conditions on the chemical, physical, and sensory properties of cheese powder. Journal of Dairy Science 98(5), 2934-2943.

Maciel, G., Chaves, K., Grosso, C., and Gigante, M. (2014). Microencapsulation of Lactobacillus acidophilus La-5 by spray-drying using sweet whey and skim milk as encapsulating materials. Journal of Dairy Science 97(4), 1991-1998.

Masters, K. (1985). "Spray drying handbook", 4th Edition. John Wiley \& Sons, New York.

Meena, G. S., Singh, A. K., Panjagari, N. R., and Arora, S. (2017). Milk protein concentrates: Opportunities and challenges. Journal of Food Science and Technology 54(10), 3010-3024.

Montagne, D. H., van Dael, P., Skanderby, M., and Hugelshofer, W. (2009). Infant formulae-powders and liquids. In "Dairy powders and concentrated products" (A. Y. Tamine, ed.), pp. 294-331. Wiley, Chichester, UK.

Morr, C., and Ha, E. (1993). Whey protein concentrates and isolates: Processing and functional properties. Critical Reviews in Food Science and Nutrition 33(6), 431-476.

O'Callaghan, D., and Hogan, S. (2013). The physical nature of stickiness in the spray drying of dairy products - a review. Dairy Science and Technology 93(4-5), 331-346.

Onwulata, C., Smith, P., Cooke, P., and Holsinger, V. (1996). Particle structures of encapsulated milkfat powders. Lebensmittel-Wissenschaft \& Technologie 29(1-2), 163-172.

Onwulata, C. I., and Huth, P. J. (2009). "Whey processing, functionality and health benefits". John Wiley \& Sons, Ames, Iowa.

Papadakis, S. E., and Bahu, R. E. (1992). The sticky issues of drying. Drying Technology 10(4), 817-837.

Patel, B., Patel, J. K., and Chakraborty, S. (2014a). Review of patents and application of spray drying in pharmaceutical, food and flavor industry. Recent Patents on Drug Delivery and Formulation $8(1), 63-78$.

Patel, H., Patel, S., and Agarwal, S. (2014b). "Milk protein concentrates: Manufacturing and applications - Technical report", Vol. 2018. US Dairy Export Council, https://www.usdairy.com/ /media/ usd/public/mpc-tech-report-final.pdf.

Paterson, A. H., Zuo, J. Y., Bronlund, J. E., and Chatterjee, R. (2007). Stickiness curves of high fat dairy powders using the particle gun. International Dairy Journal 17(8), 998-1005.

Pearce, R. J. (1992). Whey processing. In "Whey and lactose processing" (J. G. Zadow, ed.), pp. 73-89. Springer Netherlands, Dordrecht. 
Pisecky, J. (1985). Technological advances in the production of spray dried milk. International Journal of Dairy Technology 38(2), 60-64.

Pisecký, J. (1997). "Handbook of milk powder manufacture". Niro A/S, Copenhagen.

Písecký, J. (2005). Spray drying in the cheese industry. International Dairy Journal 15(6-9), 531-536.

Qi, P. X., and Onwulata, C. I. (2011). Physical properties, molecular structures, and protein quality of texturized whey protein isolate: Effect of extrusion moisture content. Journal of Dairy Science 94(5), 2231-2244.

Ramos, O. L., Pereira, R. N., Rodrigues, R. M., Teixeira, J. A., Vicente, A. A., and Malcata, F. X. (2016). Whey and whey powders: Production and uses. In "Encyclopedia of food and health" (B. Caballero, P. M. Finglas and F. Toldrá, eds.), pp. 498-505. Academic Press, Oxford.

Ranken, M. D., Kill, R. C., and Baker, C. (1997). Dairy products. In "Food industries manual" (M. D. Ranken, R. C. Kill and C. Baker, eds.), pp. 75-138. Springer US, Boston, MA.

Refstrup, E. (1995). Advances in spray drying of food products. International Journal of Dairy Technology $48(2), 50-54$.

Roos, Y. H. (2002). Importance of glass transition and water activity to spray drying and stability of dairy powders. Le Lait 82(4), 475-484.

Roos, Y. R., and Karel, M. A. (1992). Crystallization of amorphous lactose. Journal of Food Science 57(3), 775-777.

Rosenberg, M., and Sheu, T. (1996). Microencapsulation of volatiles by spray-drying in whey proteinbased wall systems. International Dairy Journal 6(3), 273-284.

Roy, I., Bhushani, A., and Anandharamakrishnan, C. (2017). Techniques for the preconcentration of milk. In "Handbook of drying for dairy products" (C. Anandharamakrishnan, ed.), pp. 23-42. John Wiley \& Sons, Ltd., Chichester, UK.

Sarode, A., Sawale, P., Khedkar, C., Kalyankar, S., and Pawshe, R. (2016). Casein and caseinate: Methods of manufacture. In "Encyclopedia of food and health", Vol. 1 (B. Caballero, P. Finglas and F. Toldra, eds.), pp. 676-682. Academic Press Elsevier Ltd., Oxford.

Schuck, P. (2002). Spray drying of dairy products: State of the art. Le Lait 82(4), 375-382.

Schuck, P. (2013). Dairy powders. In "Handbook of food powders" (B. Bhandari, N. Bansal, M. Zhang and P. Schuck, eds.), pp. 437-464. Woodhead Publishing, Cambridge, UK.

Tetra Pak (2018). "Dairy processing handbook", Vol. 2018. Tetra Pak, https://dairyprocessinghandbook.com.

Torres, J. K. F., Stephani, R., Tavares, G. M., De Carvalho, A. F., Costa, R. G. B., de Almeida, C. E. R., Almeida, M. R., de Oliveira, L. F. C., Schuck, P., and Perrone, I. T. (2017). Technological aspects of lactose-hydrolyzed milk powder. Food Research International 101, 45-53.

Tunick, M. H. (2008). Whey protein production and utilization: A brief history. In "Whey processing, functionality and health benefits" (C. I. Onwulata and P. J. Huth, eds.), pp. 1-13. John Wiley \& Sons, Ames, Iowa.

Uluko, H., Liu, L., Lv, J.-P., and Zhang, S.-W. (2016). Functional characteristics of milk protein concentrates and their modification. Critical Reviews in Food Science and Nutrition 56(7), 1193-1208.

Varnam, A., and Sutherland, J. P. (2001). "Milk and milk products: Technology, chemistry and microbiology". Springer Science \& Business Media, Surrey.

Wang, S., and Langrish, T. (2007). Measurements of the crystallization rates of amorphous sucrose and lactose powders from spray drying. International Journal of Food Engineering 3(4), 1-17.

Woo, M. (2017). Recent advances in the drying of dairy products. In "Handbook of drying for dairy products" (C. Anandharamakrishnan, ed.), pp. 249-268. John Wiley \& Sons, Chichester, UK.

Woo, M., and Bhandari, B. (2013). Spray drying for food powder production. In "Handbook of food powders" (B. Bhandari, N. Bansal, M. Zang and P. Shuck, eds.), pp. 29-56. Elsevier, Cambridge.

Young, S. L., Sarda, X., and Rosenberg, M. (1993). Microencapsulating properties of whey proteins. 1. Microencapsulation of anhydrous milk fat. Journal of Dairy Science 76(10), 2868-2877.

Zadow, J. (2012). "Whey and lactose processing". Springer Science \& Business Media, New York. 